\title{
Amadeus
}

International Multidisciplinary Journal IISSN 2525-8281

DOI: 10.14295/aimj.v5i10.163

\section{The Effectiveness of the Vaccine and the Reinfection Wave by Covid-19: What the Reports Shows}

Rivania Beatriz Novais

Lima $^{l}$,

Larissa Moreira Torres ${ }^{2}$, Glauber Magalhães Pires ${ }^{3}$, Maria Isabel Fernandes

Peixoto Furtado ${ }^{4}$, Ana Emilia Formiga Marques $^{5}$
Abstract: COVID-19 is a disease caused by the new coronavirus designated SARS-COVS2. Discoveries about the particularities of COVID-19 are constant and challenging. Currently, it has been proven that the recurrence of the disease in the same individual is possible due to the variants that the virus has. This new reality has led to discussions about the real effectiveness of the vaccine in controlling the pandemic. Objective: To obtain, through updated and reliable literature, the main data on the effectiveness of the vaccine. This comment reviewed current articles from the year 2020 to 2021, published by journals such as The Lancet, CNN, BCC and others. Further studies were needed to prove the action of passive immunization of the new variants. Recently, epidemiological studies have shown that coronavirus infection and mortality rates are falling as vaccination progresses.

Keywords: Vaccine; Covid-19; SARS-CoV-2 infection; Coronavirus.

\footnotetext{
${ }^{1}$ Acadêmica de Medicina da Faculdade de Medicina Estácio de Juazeiro do Norte. rivania.bnovais@ gmail.com

2 Acadêmica de Medicina da Faculdade de Medicina Estácio de Juazeiro do Norte. Imoreiratorres@ gmail.com

${ }^{3}$ Acadêmico de Medicina da Faculdade de Medicina Estácio de Juazeiro do Norte.

glaubermpires.yahoo.com@gmail.com

4 Acadêmica de Medicina da Faculdade de Medicina Estácio de Juazeiro do Norte. isabelp2111@ gmail.com

${ }^{5}$ Mestre e docente na Faculdade de Medicina Estácio de Juazeiro do Norte, Juazeiro do Norte. anaemiliaformiga@ hotmail.com
} 


\section{A Eficácia da Vacina e a Onda de Reinfecção da Covid-19: \\ O Que as Notícias Mostram}

Resumo: A COVID-19 é uma doença causada pelo novo coronavírus designado SARS-COVS2. As descobertas sobre as particularidades da COVID-19 são constantes e desafiadoras. Atualmente, ficou comprovado que a recorrência da doença em um mesmo indivíduo é possível devido às variantes que o vírus possui. Essa nova realidade tem levado a discussões sobre a real eficácia da vacina no controle da pandemia. Objetivo: obter por meio de literatura atualizada e confiável os principais dados sobre a eficácia da vacina. Este comment fez uma revisão de artigos atuais do ano de 2020 a 2021, publicados por revistas como The Lancet, CNN, BCC e outras. Foram necessários novos estudos que comprovam a ação da imunização passiva das novas variantes. Recentemente, estudos epidemiológicos mostraram que as taxas de mortalidade e infecção pelo coronavírus estão caindo com a progressão da vacinação.

Palavras-chave: Vacina; Covid-19; infecção por SARS-CoV-2; coronavírus.

\section{Introdução}

The COVID-19 is the disease caused by the new coronavirus designated SARS-COVS2, which emerged in Wuhan, China, in late 2019, and spread around the world in early 2020, responsible for the pandemic that left the global health and health authorities on high alert. It presents, in its most common form, with respiratory symptoms, with severe cases reaching $5 \%$ of the total (Munster, 2020).

The findings about the particularities of Covid-19 are constant and challenging. At the beginning of the pandemic, reinfection by SARS-COVS2 seemed unlikely, however now it is proven that recurrence of this diagnosis is possible, with cases being confirmed in Brazil and in several countries. This "new" reality has led to discussion about the real effectiveness of the vaccine in controlling the number and severity of pandemic infections (Abidin, 2021).

The first impasse in this wave of reinfection is to define what reinfection is in fact and what is just COVID-19 redetection. The virus genetic material may remain in the infected organism for a certain time even after the disease has been cured. Therefore, the criteria for differentiating whether these viral particles are from the same disease or a new one is based on RT-PCR examination and clinical presentation.

For the diagnosis of reinfection, the patient must present viral detection in two RT- 
PCR tests performed at an interval of at least 90 days and have been asymptomatic in this period or with a negative RT-PCR, in addition to the two tests that are positive for the disease, the virus must have genetic material different from each other. In redetection, the individual does not present negative RT-PCR or is not asymptomatic since the first infectious conditions (Secretaria de Saúde de São Paulo, 2020).

Through this diagnosis of reinfection, since the presence of variants of the Sars-Cov-2 strain, which are called B.1.1.7(ALPHA), B.1.351(BETA), P.1(GAMA), B.1.617(DELTA), C.37(LAMBDA), P.2 (ZETA), B.1.427(EPSILON), B.1.525(ETA), P.3(THETA), B.1.526(IOTA) and B.1617.1 (KAPPA), are already circulating in several countries (The Lancet, 2021). Therefore, the most recent questioning is about the effectiveness of the vaccine in relation to these new variants and the impact on controlling the epidemic and this new wave. In fact, vaccines against COVID-19 were developed in record time and studies on their real efficiency and impact are still being consolidated (BBC News,2021).

Previous research and experiments have already identified a great efficacy on the first known strain of Sars-Cov-2 and this already gave it an advantage in favor of its use. Nevertheless, further studies were needed that would also prove the action of passive immunization around the new variants, which has become the most recent concern in the pandemic. The research involves analysis carried out in vitro, in which scientists assess the ability of antibodies from vaccinated people to neutralize the new strains. In addition to these laboratory analyses, other assessments that perceive protection against other strains are observational studies carried out during and after the vaccination period (CNN, 2021). The British study by Public Health England identified that among fourteen and nineteen thousand patients detected with the Delta variant and who were previously vaccinated with AstraZeneca, only one hundred and twenty-two of these needed to be admitted to hospitals in England, thus this decreased by $92 \%$ of admissions (Stowe et al., 2021). In that same study, the efficacy of the Pfizer vaccine was evaluated, which showed to be $96 \%$ effective against hospitalizations after the second dose.

Recently epidemiological studies have shown that Covid-19 mortality and infection rates are falling as vaccination progresses. About six months after the start of mass vaccination in Brazil, some advances have already been observed, such as the reduction in mortality of the elderly over 60 years, which in June of two thousand and twenty corresponded to $77 \%$ of all deaths and this year it dropped to $45.7 \%$, according 
to data released in the epidemiological bulletins of the Ministry of Health. This group was the first to feel the impact of immunization, as it was a priority in the national vaccination order (UOL, 2021).

It is believed to reduce immunity against the virus, due to a general reduction in the immune response, evidenced in blood donors with reduced $\mathrm{IgG}$ titers, since the resurgence of cases occurred, in Manaus, for example, 7-8 months later the first peak of the disease. However, a study from the United Kingdom warns that the decrease in immunity, alone, does not justify reinfections, which also go against the justification of the resurgence by a relaxation of sanitary measures, since the restrictive measures, in Manaus, intensified in November 2020 and the health crisis caused by mass hospitalization took place in January 2021 (Sabino, 2021).

Even today, in the universe of Covid-19 and vaccines, many questions remain. How is the true protective immunity acquired? After the infection itself or after vaccination? How long can we count with it? Will this immunity be able to reduce the spread of the virus? Do already approved vaccines have power over new strains? Although some studies claim that there is considerable effectiveness of these immunizations on new strains after the second vaccination dose, the WHO reports that further studies are needed to understand the real impact of vaccines in this context of new variants (BBC, 2021). Therefore, despite the advance of vaccination, it is necessary to maintain preventive measures, such as the use of masks, alcohol gel and social distance, which can contribute to control the original form and consequently prevent other new variants that would originate in from the initial strain (The Lancet, 2021). Clarify that the vaccine is one more tool to fight the pandemic and not the only strategy to be used.

\section{References}

Ahmed M. (2021) Vacina contra coronavírus: como saber se a vacinação está surtindo o efeito esperado. BBC. Retrieved from: https://www.bbc.com/portuguese/geral56097005

BBC (2021). Delta, Gama, Beta: quais são as principais variantes da covid e quanta proteção as vacinas oferecem? Retrieved from: https://www.bbc.com/portuguese/geral-57695556

Brechara V. (2021). Vacinas são eficazes contra a variante Delta da Covid-19? Veja o que se sabe até agora. Retrieved from: https://jovempan.com.br/noticias/brasil/vacinassao-eficazes-contra-a-variante-delta-da-covid-19-veja-o-que-se-sabe-ate-agora.html 
Gluckman P. (2021). Future scenarios for the COVID-19 pandemic. The Lancet. Retrieved from: https://www.thelancet.com/journals/lancet/article/PIIS0140$\underline{6736(21) 00424-4 / f u l l t e x t}$

Goddard A F (2021). SARS-CoV-2 variants and ending the COVID-19 pandemic The Lancet. Retrieved from: https://www.thelancet.com/journals/lancet/article/PIIS01406736(21)00370-6/fulltext

Naiunu F. (2020). SARS-CoV-2 reinfection and implications for vaccine development, Human Vaccines \& Immunotherapeutics, 16:12, 3061-3073, DOI: $\underline{10.1080 / 21645515.2020 .1830683}$

Rocha L. (2021). O que a ciência sabe sobre o impacto das variantes na eficácia das vacinas. CNN. Retrieved from:

https://www.cnnbrasil.com.br/saude/2021/06/30/o-que-a-ciencia-sabe-sobre-oimpacto-das-variantes-na-eficacia-das-vacinas

Sabino E. C. (2021) Resurgence of COVID-19, in Manaus, Brazil, despite high seroprevalence. The Lancet. Retrieved from: https://www.thelancet.com/journals/lancet/article/PIIS0140-6736(21)00183-5/fulltext

STOWE, J. et al. (2021). Effectiveness of COVID-19 vaccines against hospital admission with the Delta (B. 1.617. 2) variant. Public Health England.

Teixeira L.B. (2021). Mesmo lenta, vacinação aponta para queda de mortes por COVID. UOL Retrieved from: https://www.uol.com.br/vivabem/noticias/redacao/2021/07/04/impacto-vacinacaobrasil-melhoria-indices-pandemia-covid.htm

Vincent J. (2020). A Novel Coronavirus Emerging in China - Key Questions for Impact Assessment. NEJM. Retrieved from: https://www.nejm.org/doi/full/10.1056/NEJMp2000929?query=featured_coronavirus

\section{How to cite this article (APA format):}

Lima, R. B. N.; Torres, G. M. P.; Furtado, M. I. F. P.; Marques, A. E. F. (2021). The Effectiveness of the Vaccine and the Reinfection Wave by Covid-19: What the Literature Shows. Am. In. Mult. J., Jul. to Oct. (10) 5, 79-83.

Received: 8/4/2021

Accepted: 8/13/2021 